\title{
Examining the Chinese Exchange Rate Reform and the Possibility of the Chinese Yuan Becoming a Regional Trade Currency
}

\author{
Mohammed A. Hokroh ${ }^{1, *}$ \\ ${ }^{1}$ MBA (Finance), University of Leicester, Leicester LE1 7RH, United Kingdom \\ *Correspondence: Tel: 44-966-56-857-0987. E-mail: Mohammed.Hokroh@Gmail.com
}

Received: June 19, 2013 Accepted: July 29, 2013 Published: September 27, 2013

doi:10.5296/rae.v5i3.3867ＵRL: http://dx.doi.org/10.5296/rae.v5i3.3867

\begin{abstract}
This paper analyzes the reasons and effects of the Chinese exchange rate reform (Yuan appreciation), explained and assess Hu Xiaolian's (deputy governor of the People's Bank of China and the former director of the State Administration of Foreign Exchange in China) claims about the reform of China exchange rate system. The paper also explores the possibility of the Chinese Yuan becoming a regional trade currency. A summary with key point is also provided.
\end{abstract}

Keywords: Chinese exchange rate; Chinese rate reform 


\section{Macrothink}

\section{Introduction (China's Exchange Rate Reform)}

\subsection{Historical Context}

The fix of the Chinese Yuan to the United States (U.S.) dollar had been in place since 1994. The trade imbalance between the U.S. and China has led some scholars to believe that China is manipulating its currency to hold down the dollar prices of its goods in order to create a trade advantage that contributes to the loss of U.S. jobs and businesses (Krugman cited in Fair 2010). In February 2005, the U.S. congress proposed an imposed tariff of $27.5 \%$ on Chinese goods unless China raises the value of its currency by the same percentage (Tatom 2007).

Due to this imposed pressure (Zhang 2009), the Chinese government announced a change in its exchange rate system from the fixed rate to a more manageable system (floating rate) on July $21^{\text {st }} 2005$ which was regarded as a historical change in China (Ogawa et. al. 2006).

\section{Discussion}

\subsection{Empirical Evidence}

During a one year cycle (from July 2005 to July 2006), the Yuan appreciation to the U.S. dollar appeared to be in line with the inflation difference between the two countries which justified the Purchasing Power Parity (PPP) (Zhang 2009) and (Pilbeam 2006). This encouraged scholars such as McKinnon cited in Zhang (2009) to suggest that the annual inflation difference between China and U.S. should be followed as a model. This point of view was challenged during mid-2006 after a significant regime change (Zhang 2009).

Before mid-2006, China had an adequate monetary control on capital inflows and the expected appreciation was more modest. The People's Bank of China (PBC) could sterilize excess foreign exchange accumulation to prevent excess money growth and keep inflation rate between 2 to $3 \%$ which is lower than the U.S. However, with the increasingly fast RMB appreciation after mid-2006, the PBC could not hold back the excess money growth due to the upsurge of capital inflows. Consequently, inflation in China started to rise and exceeded that in the U.S.

During the period from October 2006 to November 2007 inflation rate reached $1.4 \%$ and by time implicated the assessment of a sensible RMB/USD exchange rate movement. 


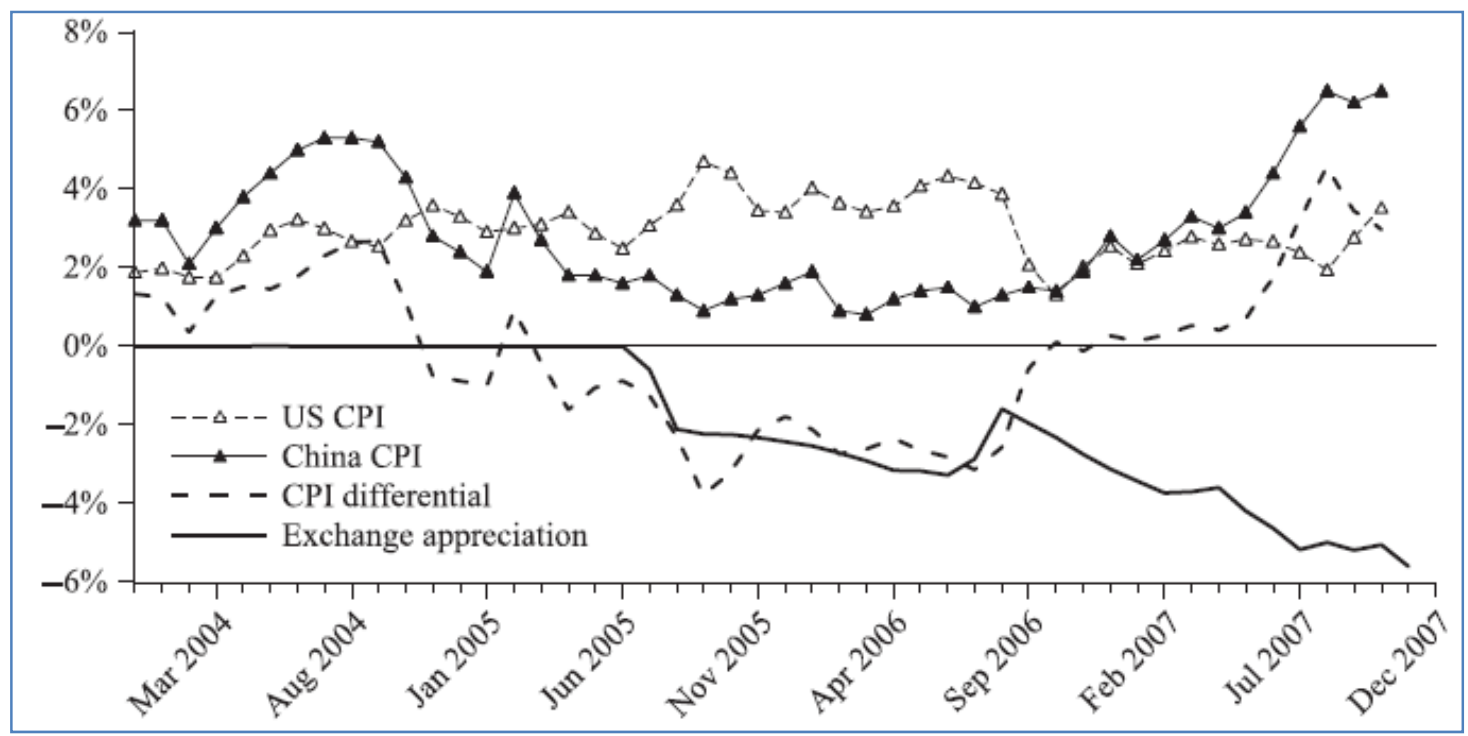

Figure 1: China-US Inflation Differential and the RMB/USD Exchange Rate Appreciation (source: Zhang 2009)

The interest rate differential between China and U.S. was another key exchange rate determinant. At late 2006, the interest rate differential has witnessed a noticeable decline with downward tending of the dollar interest rate while the RMB interest rate crawled up. Theoretically, if China's financial system were liberalized by the interest rate determined by the market, then one would expect that the upward crawl in the Yuan tends to bid down nominal interest rates on RMB assets. However, it is not the case (see figure 2). Figure 2 shows a comparison between one year RMB interest rates of China Central Bank notes and one year dollar interest rates quoted in London (LIBOR) from January 2004 to November 2007.

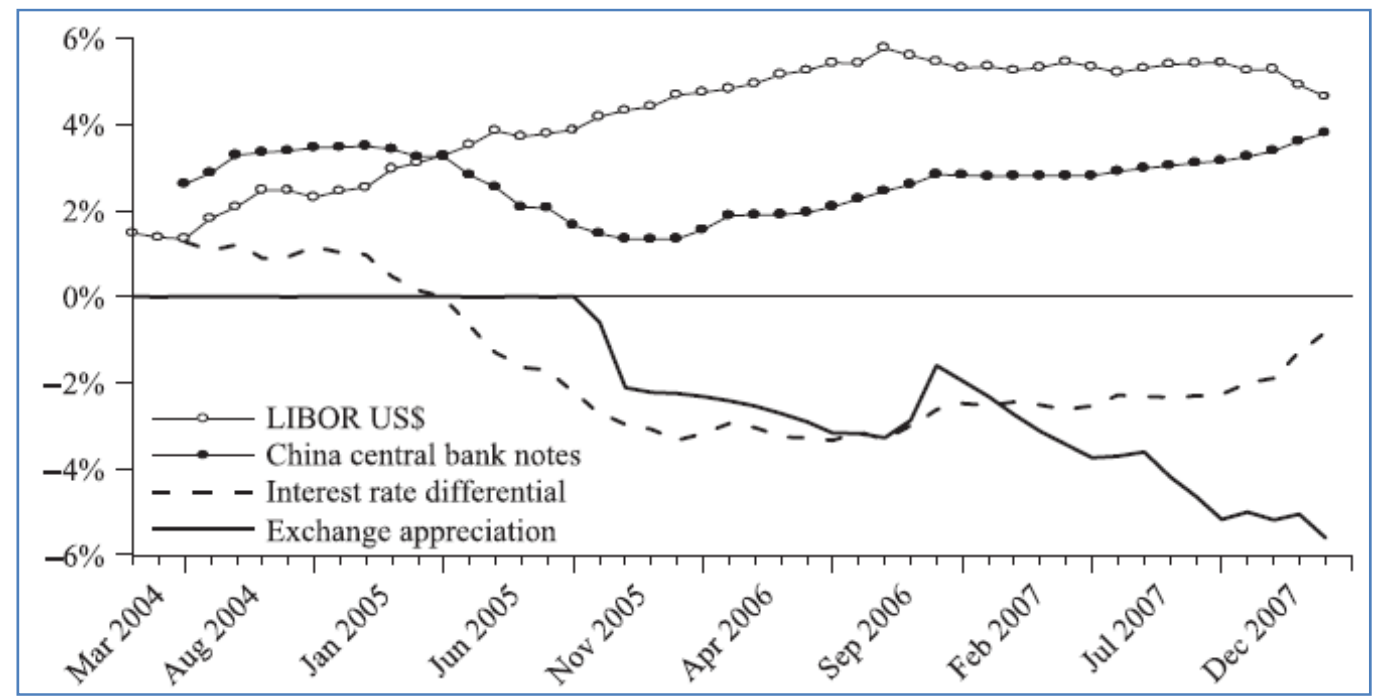

Figure 2: One-year Interest Rates Differential and the RMB/USD Exchange Rate Appreciation (source: Zhang 2009) 


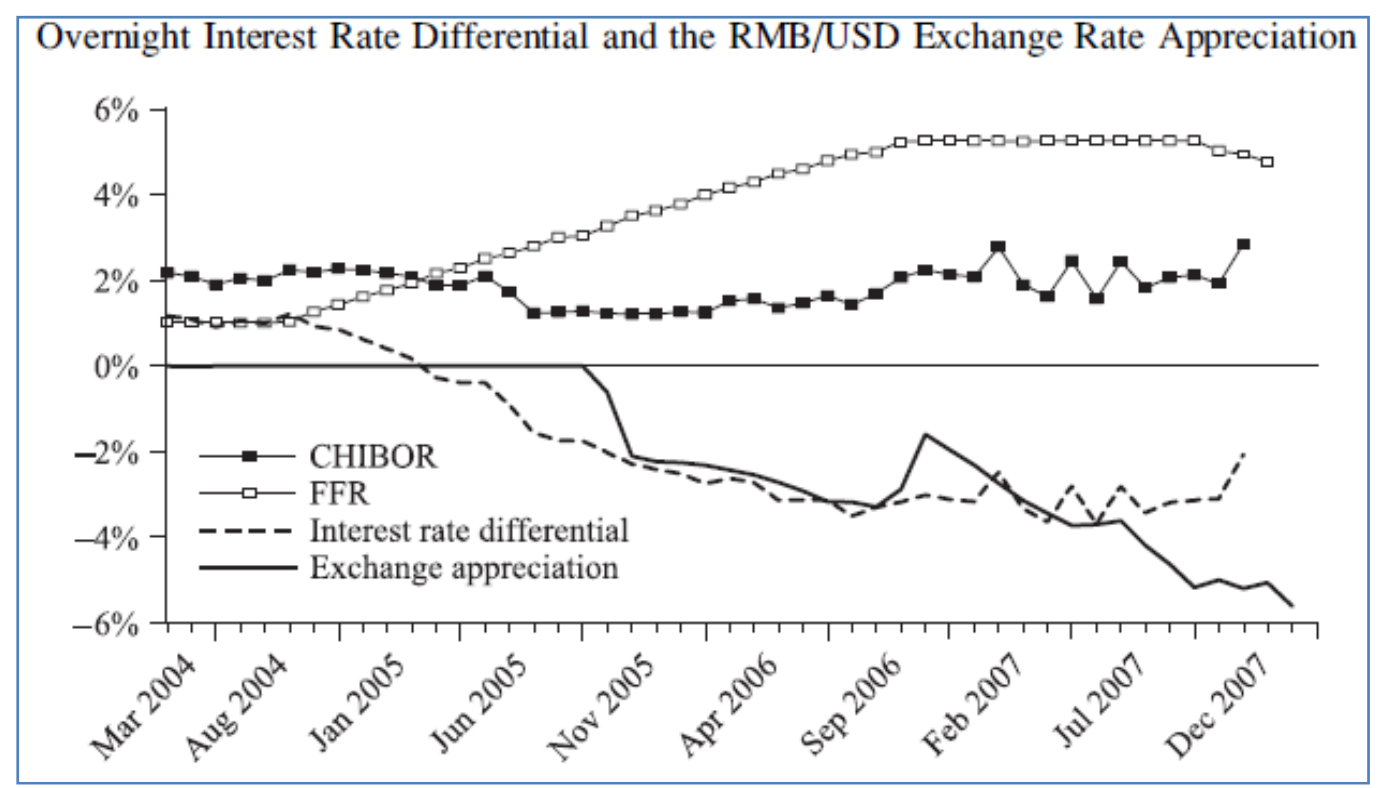

Figure 3: Overnight Interest Rate Differential and the RMB/USD Exchange Rate Appreciation (source: Zhang 2009)

Figure 3 shows a comparison between China interbank offer rate (CHIBOR) and overnight rate for U.S. (the federal fund rate). Because of inflation, the interest rate differential between China and U.S. has deviated from the path of the Yuan appreciation. As illustrated, before early 2007 the interest rate differential between China and U.S. matched the RMB appreciation but deviated substantively after that.

The Chinese government worked hard to maintain "stable prices" in order to control domestic inflation. The PBC raised the RMB interest rate six times during 2007. On ther other hand, the U.S. has encouraged the Federal Reserve to ease its monetary policy by reducing interest rates to response to the credit crunch. As a result the interest rate differential between U.S. and China was reduced as illustrated in figures 2 and 3.

\subsection{During 2008-2010}

In July 2008, the Chinese government started to peg its currency back to the USD (6.83 Yuan/Dollar) in order to enhance exports during difficult economic conditions. In spite of that, the Chinese exports fall dawn for 13 months decreasing China's trade surplus by $34 \%$ during 2009. Consequently, the trade gap between the U.S. and China ballooned to $\$ 227$ billion causing American politicians to call for action in order to restrain what they have perceived to be "unfair trade practices by China” (Miller 2010).

The trade imbalance encouraged American and Chinese economists to propose that a discrete Yuan appreciation against the dollar would have the predictable outcome of reducing China's trade surplus and U.S. trade deficit.

The Chinese government announced on June $19^{\text {th }}, 2010$ that it is unhooking its two year old peg of around 6.83 Yuan per dollar to a more flexible exchange rate regime. After June 19, the Yuan has depreciated against the Dollar to reach 6.73 Yuan per Dollar by September 2010. 
(McKinnon 2010) Because inflation in China was significantly higher compared to that in the U.S. especially in the $2^{\text {nd }}$ half of 2010 (the annual CPI inflation was more than $5 \%$ points higher in China than the U.S.), the RMB has been appreciating more rapidly against the dollar in real, inflation adjusted basis (Geithner 2011).

\section{Hu Xiaolian's Claims Analysis and Assessment}

\subsection{Claims Analysis}

“Adopting a more flexible exchange-rate regime serves China's long-term interest as the benefits... far exceed the cost in reorganising industries and removing outdated capacity" $\mathrm{Hu}$ Xiaolian's (deputy governor of the People's Bank of China and the former director of the State Administration of Foreign Exchange in China) argues.

Analysts (e.g. Geithner 2011) indicate that if the Chinese government is undertaking a relaxation of restrictions on the use of RMB, then the exchange reform will gradually help the Chinese monetary authority manage the level of exchange rate that will contribute to a more market-determined exchange rate over time.

In 2010, the Chinese economy grew by $10.3 \%$ compared to $9.2 \%$ in 2009 indicating recovery from the global financial crisis.

The Chinese government developed strategic objective and programs aimed at rebalancing the economy to rely more on domestic demand for growth. The Chinese government realizes that the exchange rate reform is one way to resolve the imbalance.

$\mathrm{Hu}$ Xiaolian's argues that a freer exchange rate liberates China's monetary policy, spurs innovation in China exports industries and channels investment to its service sectors. Chinese monetary authority increasingly turned toward containing inflation. Economic recoveries in other parts of the world have begun to decrease the gap between China's growth and that of its trading partners. As a result, the contribution of real net exports to growth increased.

In order to contain the rising prices in both goods and property markets, China shifted to less simulative monetary and fiscal policies. China managed to decrease its fiscal deficit from $2.3 \%$ of GDP in 2009 to $1.6 \%$ in 2010. The PBC increased the amount of reserves (required by large commercial banks to hold at the central bank) from $15.5 \%$ of total deposits at the beginning of 2010 to 19\% as of mid-January 2011. The PBC also raised China's benchmark 1-year lending rate 50 basis points from $5.31 \%$ to $5.81 \%$ (though it is less than the rise in the inflation rate). China's international trade has also recovered to rise up to $31.4 \%$ in 2010 which is $10.2 \%$ above their 2008 level. Imports also rose 39.1\% in 2010 which are $23.6 \%$ above their 2008 level. In 2010 the goods and service trade surplus was 4.0\% of GDP compared to 7.7\% in 2008 . (Geithner 2011)

\subsection{Claims Analysis}

There are economic links among countries that have to be accounted for when examining the effects of changes in exchange rates. Scholars such as Fair (2010) used a Multi-County (MC) 
econometric model to estimate the effects of Yuan appreciation on the Chinese economy reported the following effects: First, the Yuan appreciation leads to a decrease in China's import prices which leads to a decline in Chinese domestic prices. The decline in the Chinese domestic prices and the decrease in the world price of exports in Yuan (due to appreciation) lead to a decrease in Chinese export prices in Yuan. Second, the increase in dollar price of Chinese exports relative to the dollar price of other countries' exports leads to a decline in the demand for Chinese exports. The decline in exports negatively affects China's GDP which consequently negatively affects the total Chinese imports. Ma and Lu (2010) point out that the RMB appreciation on the Chinese economy is modest. For example, if the Yuan appreciated at $3 \%$ against the USD per year, it reduces GDP growth by $0.2 \%$ and export volume by $0.7 \%$. Moreover, RMB appreciation has a negative effect on sectors such as shipping, electronic components and computers. However, the Yuan appreciation has long-term positive for consumption. For instance, it is expected that the Yuan appreciation will boost consumption by $6.5 \%$ (cumulatively) and reduce exports by 11\% (cumulatively) within the next five years.

Fair (2010) indicates that the effect of Yuan appreciation on other economies particularly the U.S. are as follows: first, the U.S. import prices are high due to higher prices of Chinese imports which lead to an increase in the U.S. domestic prices. This leads to an increase in the price of U.S. exports. A decrease in real wealth and real disposable income are led by the increase in the U.S. price level. For example, according to the U.S. estimated interest rate rule, the interest rate responds positively to an increase in inflation and negatively to a fall in output (GDP). Accordingly, the U.S GDP is affected negatively and positively.

Many economists and politicians perceive that the Yuan appreciation against the dollar would result in reducing China's trade surplus and U.S. trade deficit. However, scholars such as McKinnon (2010) argue that China's trade surplus is only a reflection of its net surplus of saving over investment and vice versa for the saving-deficient in the U.S. The Yuan appreciation would reduce corporate profitability and some corporate saving but there is no presumption that saving over investment would move if the Yuan is appreciated. Investment in China would sharply fall if it is seen to be more expensive country in which to install productive capacity and produce from it. Because China currently has high investment to GDP ratio (around $40 \%$ to $45 \%$ ), it has a long way to fall and with the greater sensitivity of investment to the exchange rate system, the presumption would be that China's trade (net saving surplus) would increase with the Yuan appreciation.

The decline in the probability of trade imbalance between China and the U.S. because of China's currency appreciation should help lift market sentiment for risky asset classes in the short term. After the PBC announcement, investors will expect a modestly positive reaction from the Chinese equity markets (e.g. airlines), because of investors' expectations of a strong Yuan appreciation. However, it is arguable that the foreign exchange market and allow the "market" to decide what the rate should be when at the same time it has a huge net saving (trade) surplus. 


\section{Yuan Currency}

\subsection{Yuan as Regional Currency}

In order for a currency to gain international importance, there has to be a strong demand for it by three entities: the world's traders, the world's investors and the world's central bankers. The currency has to be considered as a medium of exchange for foreign trade settlement, a unit of account for denominating international financial transactions and a store of value for central banks' foreign exchange reserves.

In addition to the three elements of an international currency, there are three determinants of currency internationalization. They are the size of an economy and its trade volume, the breadth, depth and liquidity of its capital markets and third, the stability and convertibility of its currency. For instance, the dollar, euro and yen account for $28.5 \%, 22.0 \%$ and $11.2 \%$ of the world GDP respectively. (Wu 2009) However, compared to China, it is only $4.6 \%$ as shown in figure 4:

\begin{tabular}{l} 
Comparison of Reserve Currencies \\
\begin{tabular}{|l|c|c|c|c|c|c|c|c|c|}
\hline \\
Currency
\end{tabular} \\
\hline
\end{tabular}

Figure 4: Comparison of Reserve Currencies (source: Wu 2009)

China accounts for $5.1 \%$ of the world's trade volume which is lower than the U.S. trade volume that accounts for $13 \%$. China also works in expanding the role of its currency to evolve into a major currency for cross-border trade settlement with countries such as Vietnam, Cambodia, Russia and Mongolia. In 2008, China government announced pilot program to allow provinces such as the Yangtze River Delta, Guangxi and Yunnan to use the Yuan to settle commercial transactions with selected members of the Association of Southeast Asian Nations.

China also has entered into two-sided currency-swap agreements with a number of trading partners in order to mitigate exchange-rate risks arising from trade settlement in the dollar. For instance, in 2008, the PBC signed currency-swap agreements with South Korea, Indonesia, Malaysia, Argentina, and Belarus with a total value of RMB 650 billion. Consequently, the Chinese government is starting to push the RMB on a liberalization path to raise its profile as a regional medium of exchange. 
For any country planning to internationalize the role of its currency, it should offer open and sophisticated transaction venues where foreign dealers can trade a range of currency-denominated financial products and place regulatory and macroeconomic safeguards to minimize the unit's volatility and exchange rate-related risk. This is true for countries with less restriction on capital account transactions because they are more likely to promote short-term portfolio inflows and outflows and consequently tend to facilitate high and far-reaching circulation of their currencies offshore.

When we compare the Chinese capital market with other capital markets elsewhere we can see clearly that China capital market is still in its early stage and it may take one or two decades for China to develop capital markets with comparable breadth and depth.

First, China's domestic capital market has limited opportunities for Chinese companies to fund-raising when compared to other markets worldwide. Moreover, relative to other major currency countries, China has lower equity and bond market capitalizations to GDP ratios. According to the Deutsche Bank Research cited in Wu (2009) for instance, China's equity and bond market capitalizations only account for $5.9 \%$ and $2.4 \%$ of the world's equity and bond markets respectively and the banking sector account for only $9.1 \%$ of total global bank assets.

Second, because of access barriers to China's capital markets, the interaction and openness with foreign markets are very restricted. For example, due to China's capital markets restrictions, the inward portfolio investments from 2003 to 2007 represented a mere $0.7 \%$ of the total portfolio investments globally. Third, the integration between China's capital market and the international market system is difficult because of constraints such as high transaction costs, and weak supervisory and regulatory frameworks. For example China still practices a merit-based approval system compared to registration-based systems in most overseas mature capital markets. Another constraint is the transaction costs. The average transaction cost for bonds in China is 6.3 basis points which are relatively high compared the rest of the world. For example the United Kingdom, U.S. and Japan have 1.0, 0.4 and 0.5 basis points respectively. In view of that, the Chinese financial system has to be reformed in order to compete globally through elimination of bureaucracy and substantial reduction in transaction costs.

Although some progressive steps have been taken by the Chinese government to add more breadth and depth to China's capital markets (e. g. the permit qualified foreign investors to list on the Shanghai exchange in 2010 and approve banks to issue renminbi-denominated corporate bonds), it will take some years before the Chinese capital markets can successfully be reformed to a more open and mature stage.

Although China is ranked $3^{\text {rd }}$ worldwide in absolute economic size, it remains far behind other leading economies in average per capita income level. For example, in 2007, China per capita income was equivalent to US\$2,342 and is projected to be US\$49,650 by year 2050 . However, China will still lag far behind when compared to the U.S. which is projected to have a per capita income equivalent to US\$91,683 by 2050.

\subsection{From Chinese Worker Perceptive}

In addition to the "physical" fundamental factors essential to the internationalization of a 
currency, there are also the "psychological” factors that play a supporting role. For instance, a stable currency will be more acceptable as an international currency, in the viewpoint of an investor, than a volatile one. The stability of a particular currency can be measured by its home economy's inflation rate and the acceleration of it undermines the purchasing power of that currency. For example, China has a low average annual inflation rate (1.1\%) when compared to the U.K. with $2.8 \%$, U.S. with $2.6 \%$.

Another important measure of currency stability is the unit's exchange rate volatility. This can be calculated as the standard deviation of daily percentage change in the exchange rate against International Monetary Fund's Special Drawing Rights. A calculation done by Wu (2009) yielded an average of 4.4 for the renminbi during a period of 10 years. This is low when compared to the dollar (4.5), euro (5.4) and yen (8.2) respectively (see figure 4). Currently, the renminbi lacks the primary prerequisite to become a global currency: free and full convertibility.

\subsection{From Other Countries Workers/Consumers (that trade with China) Perceptive}

Numerous workers fear that goods and services are being moved overseas and taking jobs with them contributing to an increase in unemployment. Businesses that manufacture exportable goods and services and/or compete with imported goods and services view weak exports compared to imports as damaging state of affairs to both competition and local economy. For example, the U.S. largest bilateral trade imbalance is with China. However, if the RMB is undervalued, the exports from China to the U.S. are likely to be cheaper than they would be if the currency were freely traded. This will provide a boost to China's export industry and attract for foreign investment (Morrison 2008).

\section{Conclusion}

In this paper we focused on the reasons and effects of the Chinese exchange rate reform (Yuan appreciation). We explained and assessed Hu Xiaolian's claims about the reform of China exchange rate system and explored the possibility of the Chinese Yuan becoming a regional trade currency. In summary: Inflation rate is a key exchange rate determinant and because of its dynamic evolution, it has implicated the assessment of a sensible RMB/USD exchange rate movement. The exchange rate reform will help China monetary authority manage the level of exchange rate that will contribute to a more market-determined exchange rate on the long run. The exchange rate reform will help China resolve its trade imbalances through shifting economy dependence on a more domestic demand for growth. The Chinese currency still lacks the primary prerequisites to become a global currency. 


\section{References}

Fair, R. (2010). Estimated Macroeconomic Effects of a Chinese Yuan Appreciation. Business Economics, 45(4), 233-243. http://dx.doi.org/10.1057/be.2010.31

Geithner, T. (2011). Report to Congress on International Economic and Exchange Rate Policies. U.S. Treasury Department: United States.

McKinnon, R. (2010). The Case Against Exchange Rate Flexibility for China: The Plight of an Immature International Creditor' unpublished, Stanford University

Miller, D. (2010). Will China End the Yuan's Peg to the Dollar? Retrieved from http://www.nuwireinvestor.com/articles/will-china-end-the-yuans-peg-to-the-dollar-550 22.aspx (accessed 07.28.11)

Morrison, W. (2008). China's Currency: Economic Issues and Options for U.S. Trade Policy. Retrieved from http://www.fas.org/sgp/crs/row/RL32165.pdf (accessed 07.12.11)

$\mathrm{Mu}$, J., \& Lu, W. (2010). Quantifying the impact of RMB appreciation. Retrieved from http://www2.china.ahk.de/news/pdf/QuantifyingRMBImpact.pdf (accessed 7.26.11)

Ogawa, E., \& Sakane, M. (2006). Chinese Yuan after Chinese Exchange Rate System Reform. China and World Economy, 14(6), 39-57. http://dx.doi.org/10.1111/j.1749-124X.2006.00044.x

Pilbeam, K. (2006). International Finance. Palgrave Macmillan: United Kingdom.

Tatom, J. (2007). The US-China Currency Dispute: Is a Rise in the Yuan Necessary, Inevitable or Desirable? Global Economy Journal, 7(3), 1-13. http://dx.doi.org/10.2202/1524-5861.1298

Wu, F. (2009). The Renminbi Challenge the Future Role of the Chinese Currency. Retrieved from http://www.international-economy.com/TIE_F09_Wu.pdf (accessed 7.4.11)

Zhang, C. (2009). Excess Liquidity, Inflation and the Yuan Appreciation: What Can China Learn from Recent History? The World Economy, 14(6), 39-57.

\section{Copyright Disclaimer}

Copyright reserved by the author(s).

This article is an open-access article distributed under the terms and conditions of the Creative Commons Attribution license (http://creativecommons.org/licenses/by/3.0/). 